\title{
The Role of Technology in the Marketing Communications Industry: An Exploratory Study of the Impact of North American Influence on Local Business in Trinidad and Tobago
}

\author{
Prahalad Sooknanan1, Karen Crichlow ${ }^{2}$ \\ ${ }^{1}$ University of Trinidad and Tobago, O'Meara Campus, Trinidad and Tobago \\ ${ }^{2}$ Arthur Lok Jack, Graduate School of Business, University of the West Indies, Mount Hope, Trinidad and Tobago \\ Email: Prahalad.sooknanan@utt.edu.tt
}

Received 25 May 2014; revised 30 June 2014; accepted 25 July 2014

Copyright (C) 2014 by authors and Scientific Research Publishing Inc.

This work is licensed under the Creative Commons Attribution International License (CC BY). http://creativecommons.org/licenses/by/4.0/

(c) (†) Open Access

\begin{abstract}
New communication technologies such as the Internet are causing sweeping changes within the global marketing communications industry. Therefore, the implications of e-marketing for business in Trinidad and Tobago are profound as seen in a national plan to address this need. This study examines the efforts of local businesses and consumers to get on the e-marketing bandwagon already commonplace in the U.S. Two surveys were conducted among local businesses and local consumers to determine their readiness and/or success. In spite of governmental efforts to expand Internet capabilities, lethargy and lack of access still plague local businesses. This contrasts with local consumers who are more receptive to e-marketing expressing an increasing demand for online information. It is therefore imperative for the T\&T government to address the deficiencies in its ICT plan so that local businesses and consumers can catch up with the rest of the world before the gap widens to a point where it becomes impossible to do so.
\end{abstract}

\section{Keywords}

Internet, e-Marketing, ICT, Global Marketing, Local Business, North American Influence

\section{Introduction}

According to Drucker (2001), a business enterprise has only two basic functions: marketing and innovation. 
Therefore, regardless of its product, service or category, marketing is of strategic importance to a business. In the past decade, the environmental dynamics within which businesses and marketers operate have evolved significantly. The rapid proliferation of the Internet had indeed revolutionized the manner in which businesses can relate externally with consumers as well as internally with each other. Choices now abound in terms of available media, which today include a wide assortment of traditional media (television \& radio), Internet-based marketing alternatives (collectively also known as "e-marketing") as well as non-traditional, non-mass media alternatives such as direct mail and event marketing. Consumers meanwhile are becoming increasingly sophisticated and demanding in terms of the brands they choose and the time, channel and manner in which these brands communicate with them. These trends mean that to be truly effective at achieving consumer satisfaction and maintaining consumer loyalty, today's marketers are required to be more creative and customer focused than that in past years.

In Trinidad and Tobago (T\&T), the marketing communication landscape is also changing and so too is the local consumer. While the rate of change might differ from countries such as the United States, the ramifications could be quite similar. T\&T exists in an increasingly global market place and there is much that local consumers and businesses can learn from the experiences and trends in other countries, as it relates to the evolving marketing communication industry.

The advent of new communication technologies has revolutionized the form and manner of our communicative behavior. Specifically with reference to the Internet, this has impacted on the marketing communication practices of businesses elsewhere but it is unclear to what extent it is impacting local businesses and consumers.

The North American consumer, always on the cutting edge of technology, today determines how, when and where marketers communicate with them. North American companies, on the other hand, have also quickly learnt how to maximize and focus their limited exposure time by delivering increasingly targeted or customized marketing messages, using e-marketing channels. The Internet, therefore, is already an indelible part of the North American culture and business landscape, and has brought sweeping changes in communication, marketing, commerce, and entertainment.

In Trinidad and Tobago, the government too has recognized the important role that the Internet plays in the ongoing development of the nation, its policies, its business sector and its people. As part of its "Vision 2020", in 2003 the government prepared a National Information and Communications Technology (ICT) strategy and developed a program entitled "Fast Forward" that defined a roadmap to an online society and knowledge-based economy by the year 2008 .

The Ministry of Public Administration \& Information’s “Fast Forward” Summary Brochure (Ministry of Public Administration \& Information, 2003: p. 3) states:

Information and Communication Technology (ICT) is making our world smaller every day. The worldwide reach of the Internet and advances in telecommunications and computers can now place valuable information, images and knowledge at everyone's fingertips-anytime and anywhere. Access to this level of information and knowledge has never been possible before. Applied wisely and managed effectively, increased connectivity can help in important ways such as education, health, employment, social services, equity and justice. It can increase productivity in every area and shape the future of our children, our people, and our country, to provide us all with new and exciting opportunities.

According to the National ICT Plan Trinidad and Tobago 2012-2016, the government has identified ICT as one of seven inter-connected pillars for sustainable national development. Dubbed Smart TT, it is a comprehensive five-year strategy that encapsulates five themes: Innovation and Human Capital Development, Access and Digital Inclusion, e-Business and ICT Sector Development and e-Government. This initiative is a successor to the previous plan that was called Fast Forward and focuses on creating and promoting local digital content as well as increasing the accessibility and affordability of technologies. While the strategic thrust is bridging the digital divide a key initiative is stimulating ICT demand to encourage e-commerce adoption (Ministry of Planning and Development, 2010). Over the past few years, Caribbean countries have been steadily moving up in global ICT ratings and it is anticipated that by 2027 Trinidad and Tobago aims to become an industrial and consumer ICT research centre and a net exporter of ICT services.

This study seeks to assess the impact of the Internet on marketing communication practices of business. Firstly, focusing on the United States, it aims to reveal the Internet's evolution and role within the North American marketing mix. Secondly, it seeks to gauge the current level of Internet usage and receptiveness amongst both local businesses and local consumers. To this end, the following research questions were posed: 
a) Has the Internet had a significant impact on North American marketing communication practices and if so, in what ways?

b) To what extent are local consumers and businesses receptive to and/or currently engaged in e-marketing activities?

It was expected that the findings of the study would reveal that marketing communication is a very different process than it was before the proliferation of the Internet and that local consumers and businesses have embraced it. Alternatively, it could reveal that the Internet has had minimal effect on marketing activities thus far, and that local consumers and businesses lag behind in terms of Internet use for personal and business marketing activities.

\section{Literature Review}

There is clear evidence that the communication environment in which we live today is starkly different from that of our parents and our children. Applegate, Austin and McFarlan (2002) describe the effect of the commercialization of the Internet as seismic while Schneider (2003) refers to the Internet as one of the most amazing technological and social accomplishments of the last century. Amor (2002) illustrates this dramatic as follows:

Nowadays we can buy goods online, book vacations or have texts translated over the Internet in an instant. Home banking, for example, is one application that is already provided by most banks around the world. Public administration has discovered the Internet as a means to talk to the general public at election times and it will not be long before we see general elections decided on the Internet... Online advertising moves commercials into new dimensions, as you are now able to place your advertisement on the desktops of a particular target group in real time (pp. xxxiii, 176).

Rapid developments in telecommunication have both facilitated and fuelled consumer demand for information that is relevant, personalized and convenient as opposed to information that is standard, static and timebound. In describing these developments, PricewaterhouseCoopers (2003) notes:

Instead of content that gets pushed to consumers at a time selected by the content provider, it will be pulled from the network by consumers for use at a time of their choosing. The on-demand availability and growing choice of content will lead to personalized consumption, replacing the older model of an aggregate audience that watches at the same time. The relationship of content providers to consumers will change from the one-to-many broadcast model to the one-to-one personalized model, enabling consumers to immediately satisfy their content requirements and enabling advertisers to tailor their material to the individual consumer (p. 13).

The Internet (or Interconnected Network) was created in 1969 as the result of a United States governmentsponsored project. It was initially used by universities and academic departments in the United States and was then handed over first to the National Science Foundation (NSF), and then later to private sector interests. The widespread adoption of the Internet by businesses in the mid-1990s was facilitated by such inventions as the client-server system known as the World Wide Web, hypertext transfer protocol (HTTP), the Uniform Resource Locator (URL) and Hypertext Mark-up Language (HTML), all of which were invented by Tim Berners-Lee. The ensuing years saw even further developments that eventually heralded the broadcast of the Internet to millions of business and home users globally.

The Internet's impact on marketing communication is evident by the shifting of marketing dollars of U.S. companies away from traditional media and towards emerging media such as the Internet and Direct Marketing. In the United States, according to a study by Universal McCann (2006), as recently as in 2000 a company's typical marketing budget would have been allocated primarily amongst mass television ( $18.1 \%$ of total advertising spend), radio (7.8\%) and press (19.8\%). In 2005, the picture was very different with as much as $23.5 \%$ having been spent on Internet advertising and Direct Mail, while mass television (Broadcast TV) dropped to $16.6 \%$ of total advertising spent. Figure 1 illustrates these trends in greater detail.

In its review entitled "The Decade in Online Advertising 1994-2004", DoubleClick (2005, April) noted that the Internet which was virtually unheard of just over a decade ago, is today a vital part of most American's lives. Inside this review, Jim Stengel, Global Marketing Officer for Procter \& Gamble and chairman of the USA Association of National Advertisers, is mentioned as describing two "sea-changing trends" that are largely respon- 
sible for the rapid transformation of the U.S. media and marketing landscape. Firstly, today's savvy marketers are demanding greater accountability for their advertising spend-something that traditional media has largely been unable to provide. Secondly, consumers are increasingly dictating their own media and marketing experiences as they deal with a vast array of media choices (e.g. TV, vs. Internet vs. TiVo) and a growing volume of marketing messages directed towards them.

One of the key contributors to the rapid increase in popularity and use of the Internet as the marketing communication channel of choice has been the rapid penetration of broadband Internet to households. Broadband Internet facilitates faster downloads and always-on connectivity perfect for today's interactive Internet content and other purposes. In the United States, broadband's growth rate has surpassed that of other recent technologies, such as mobile phones, and according to Edison Media Research (2002) broadband consumers in the United States spend fifty percent more time and sixty-four percent more money shopping online than their dial-up counterparts. DoubleClick (2005) further notes that by December 2004, 54\% of home Internet connections were broadband, a 31\% increase from December 2003.

PricewaterhouseCoopers (2003) summed up this evolution of the Internet and its impact on marketing communications in Figure 2:

\begin{tabular}{|c|c|c|c|c|c|c|c|c|c|c|c|c|}
\hline Medium & & 2000 & & 2001 & & 2002 & & 2003 & & 2004 & & 2005 \\
\hline Newspaper & $\$$ & 49,050 & $\$$ & 44,255 & $\$$ & 44,031 & $\$$ & 44,843 & $\$$ & 46,935 & $\$$ & 49,618 \\
\hline Magazines & $\$$ & 12,370 & $\$$ & 11,095 & $\$$ & 10,995 & $\$$ & 11,435 & $\$$ & 12,121 & $\$$ & 13,006 \\
\hline Broadcast TV & $\$$ & 44,802 & $\$$ & 38,881 & $\$$ & 42,068 & $\$$ & 41,932 & $\$$ & 46,020 & $\$$ & 46,675 \\
\hline Cable TV & $\$$ & 15,455 & $\$$ & 15,736 & $\$$ & 16,297 & $\$$ & 18,814 & $\$$ & 21,069 & $\$$ & 22,568 \\
\hline Radio & $\$$ & 19,295 & $\$$ & 17,861 & $\$$ & 18,877 & $\$$ & 19,100 & $\$$ & 19,779 & $\$$ & 20,981 \\
\hline Yellow Pages & $\$$ & 13,228 & $\$$ & 13,592 & $\$$ & 13,776 & $\$$ & 13,896 & $\$$ & 14,035 & $\$$ & 14,499 \\
\hline Direct Mail & $\$$ & 44,591 & $\$$ & 44,725 & $\$$ & 46,067 & $\$$ & 48,370 & $\$$ & 52,240 & $\$$ & 57,203 \\
\hline Business Papers & $\$$ & 4,915 & $\$$ & 4,468 & $\$$ & 3,976 & $\$$ & 4,004 & $\$$ & 4,094 & $\$$ & 4,252 \\
\hline Out Of Home & $\$$ & 5,176 & $\$$ & 5,134 & $\$$ & 5,175 & $\$$ & 5,443 & $\$$ & 5,790 & $\$$ & 6,080 \\
\hline Internet & $\$$ & 6,507 & $\$$ & 5,645 & $\$$ & 4,883 & $\$$ & 5,650 & $\$$ & 7,062 & $\$$ & 8,828 \\
\hline Miscellaneous & $\$$ & 32,083 & $\$$ & 29,895 & $\$$ & 30,730 & $\$$ & 31,990 & $\$$ & 34,554 & $\$$ & 36,907 \\
\hline Grand Total & \multicolumn{2}{|c|}{ S 247,472} & \multicolumn{2}{|c|}{$\$ 231,287$} & \multicolumn{2}{|c|}{$\$ 236,875$} & \multicolumn{2}{|c|}{$\$ 245,477$} & \multicolumn{2}{|c|}{$\$ 263,699$} & \multicolumn{2}{|c|}{ S 280,617 } \\
\hline
\end{tabular}

Source: Coen, 2006, Universal McCann

Figure 1. U.S. advertising volumes 2000-2005 (millions of U.S. dollars).

\begin{tabular}{|c|c|c|c|c|}
\hline $\begin{array}{l}\text { Value } \\
\text { Chain }\end{array}$ & Content & Network & Devices & Consumers \\
\hline Past & Passive & Separate & Standalone & Aggregated \\
\hline & & $\sqrt{1}$ & 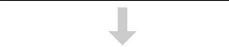 & 4 \\
\hline Future & Interactive & Converged & Networked & Personalized \\
\hline Past & $\begin{array}{l}\text { Professionally } \\
\text { created, designed for } \\
\text { one-way } \\
\text { broadcast }\end{array}$ & $\begin{array}{l}\text { Mail, retail, } \\
\text { broadcast, one-way } \\
\text { cable }\end{array}$ & $\begin{array}{l}\text { Standalone devices } \\
\text { such as TVs, stereos, } \\
\text { DVD players, PCs, } \\
\text { phones, PDAs }\end{array}$ & $\begin{array}{l}\text { Passive consumption } \\
\text { of content distributed } \\
\text { via broadcast physical } \\
\text { media }\end{array}$ \\
\hline Present & $\begin{array}{l}\text { User-generated } \\
\text { content beginning to } \\
\text { compete with } \\
\text { professional content; } \\
\text { interactivity on the } \\
\text { rise }\end{array}$ & $\begin{array}{l}\text { Content distribution } \\
\text { via Internet } \\
\text { supplements } \\
\text { broadcast and cable } \\
\text { but the two networks } \\
\text { remain separate. } \\
\text { Internet connections } \\
\text { moving to broadband } \\
\text { but still asymmetric }\end{array}$ & $\begin{array}{l}\text { Expanding pool of } \\
\text { digital devices } \\
\text { becoming more } \\
\text { interconnected, but } \\
\text { still have limited ability } \\
\text { to deliver content to } \\
\text { consumer's preferred } \\
\text { device }\end{array}$ & $\begin{array}{l}\text { Two separate content } \\
\text { consumption } \\
\text { experiences: passive } \\
\text { TV viewing for } \\
\text { broadcast, interactive } \\
\text { PC use for Internet. } \\
\text { Only TV viewing can } \\
\text { be a group experience }\end{array}$ \\
\hline Future & $\begin{array}{l}\text { Increased } \\
\text { competition from } \\
\text { user-created content; } \\
\text { more content is } \\
\text { designed for } \\
\text { interactivity }\end{array}$ & $\begin{array}{l}\text { Fiber-based networks } \\
\text { will provide } \\
\text { symmetric broadband } \\
\text { in a variety of service } \\
\text { packages }\end{array}$ & $\begin{array}{l}\text { Home media servers } \\
\text { will act as staging } \\
\text { areas, fed by content } \\
\text { providers over } \\
\text { broadband } \\
\text { connections and } \\
\text { delivered to many } \\
\text { devices }\end{array}$ & $\begin{array}{l}\text { Consumers will have } \\
\text { personalized channels } \\
\text { allowing on-demand } \\
\text { content consumption. } \\
\text { Consumption } \\
\text { experiences include } \\
\text { individual, group, and } \\
\text { online communities }\end{array}$ \\
\hline
\end{tabular}

Source: PricewaterhouseCoopers, 2003

Figure 2. The interactive, networked and personalized future. 
The conditions and trends that are fuelling this current transformation of the U.S. marketing landscape are also very much present in Trinidad and Tobago. Rapid developments in local telecommunications have occurred with the launch by TSTT of its DSL service in 2002, its EDGE service (which allows compatible mobile users to browse the Internet) in April 2006 and wireless broadband services and Blackberry and EV-DO 3G technology, both in July 2006.

In 2003, as part of the Fast Forward project, the National e-Commerce Secretariat (NeCS) (2003) conducted a survey on e-Commerce Usage and Awareness among Businesses and Households. The survey results were based on responses from 4457 (individuals 15 years and over) throughout households in Trinidad \& Tobago as well as responses from approximately 442 small, medium and large businesses covering the spectrum of representative industries.

Amongst the households, it was discovered that only 25\% owned a computer but that most of these did have internet access and in fact $22 \%$ of these made an internet purchase during the past year. However, only $35 \%$ of respondents were aware of any local e-marketing activity. From the businesses surveyed, $98 \%$ of those with Internet access used it primarily for email and only $43 \%$ had their own website. However, $73 \%$ recognized the importance of an e-business strategy and planned to implement one in the short to medium term. Some other key findings of the Household Survey are shown in Figure 3, and that of the Business Survey in Figure 4.

According to the International Telecommunications Union (2005) and Internet World Stats (2006), though Internet penetration has improved in Trinidad and Tobago over the past three to five years, it still lags behind countries such as the United States (69.1\% in 2006) and even fellow Caribbean countries such as Barbados (60\%) and Jamaica (39.6\%). Interestingly, Trinidad and Tobago's Internet 'Use Growth' rate is among the slowest in the region, as seen in Figure 5.

\section{Methodology}

Two primary research surveys were conducted for this study. Firstly, the Local Business Website survey was done to benchmark the current level of Internet use by local businesses. Local websites were chosen from amongst those listed in local online directory sites such as Who's Who TNT (2003, http://www.whoswhotnt.com) but were also randomly sought from industries likely to benefit from an Internet presence such as Consumer Packaged Goods and Retail.

Secondly, a Local Consumer Internet Use survey was conducted at Tru Valu Supermarket, Trincity Mall. Tru Valu Supermarket is a middle/upper income establishment, situated in the heart of the one of the most affluent residential districts in East Trinidad. It was selected as the location for this survey as it was assumed that its customers would also be middle/upper income individuals and would be representative of those within the population that would have access to a computer and the Internet (at home and/or at work).

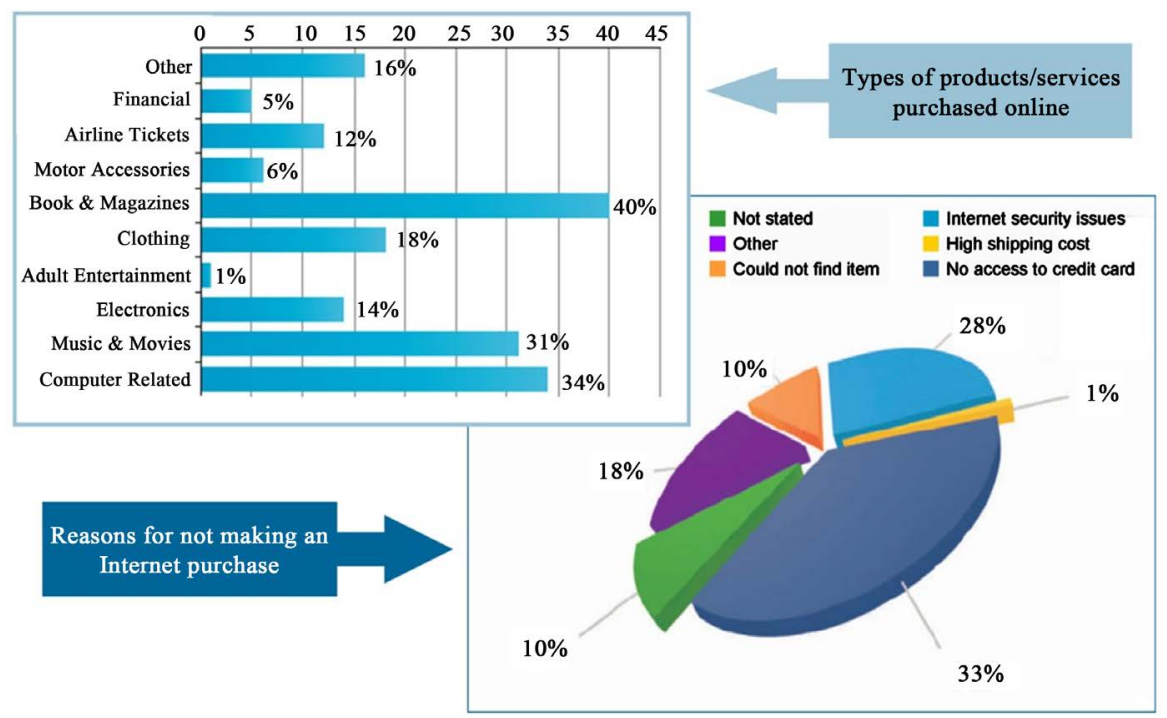

Source: National e-Commerce Secretariat, 2003, Household Survey

Figure 3. Key findings of national household survey 2003. 


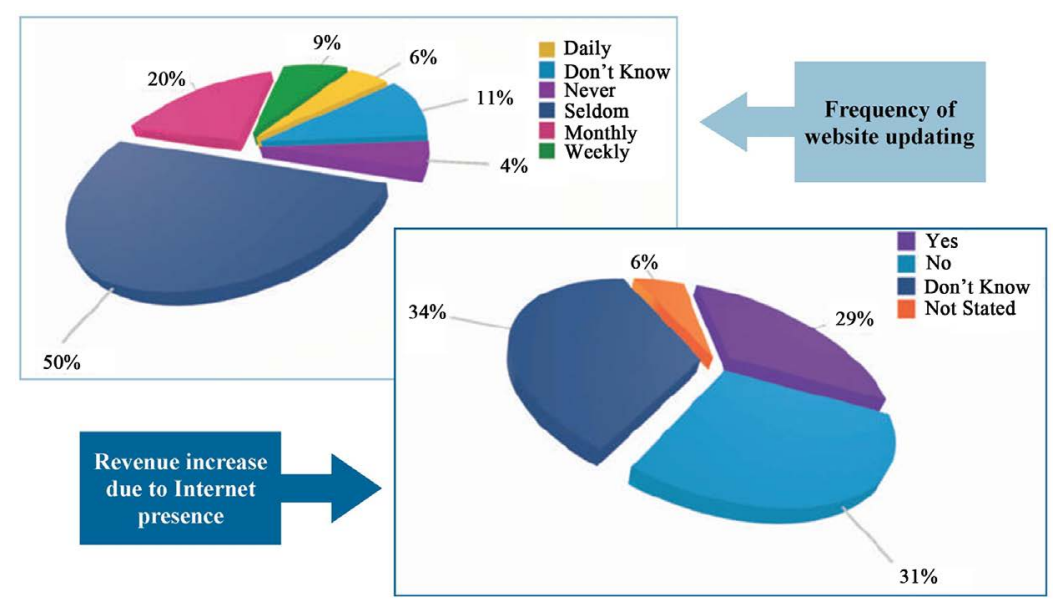

Source: National e-Commerce Secretariat, 2003, Business Survey

Figure 4. Key findings of national business survey 2003.

\begin{tabular}{|lrrrr|}
\hline Country & $\begin{array}{r}\text { Population } \\
\text { (2006 Est.) }\end{array}$ & $\begin{array}{l}\text { (Sept 2006) } \\
\text { (Snternet Users }\end{array}$ & $\begin{array}{r}\text { \% Population } \\
\text { Penetration ) }\end{array}$ & $\begin{array}{r}\text { Use Growth } \\
(\mathbf{2 0 0 0 - 2 0 0 6})\end{array}$ \\
\hline Barbados & 266,731 & 160,000 & $60.0 \%$ & $2,566.7 \%$ \\
Jamaica & $2,692,569$ & $1,067,000$ & $39.6 \%$ & $1,678.3 \%$ \\
Aruba & 70,102 & 24,000 & $34.2 \%$ & $500.0 \%$ \\
St. Lucia & 167,642 & 55,000 & $32.8 \%$ & $1,733.3 \%$ \\
Bahamas & 330,602 & 93,000 & $28.1 \%$ & $609.9 \%$ \\
Antigua \& Barbuda & 71,823 & 20,000 & $27.8 \%$ & $300.0 \%$ \\
Martinique & 397,928 & 107,000 & $26.9 \%$ & $2,040.0 \%$ \\
Puerto Rico & $3,966,468$ & $1,000,000$ & $25.2 \%$ & $400.0 \%$ \\
Grenada & 100,429 & 19,000 & $18.9 \%$ & $363.4 \%$ \\
Trinidad \& Tobago & $\mathbf{1 , 3 2 0 , 3 8 3}$ & $\mathbf{1 6 0 , 0 0 0}$ & $\mathbf{1 2 . 1} \%$ & $\mathbf{6 0 . 0} \%$ \\
Dominican Republic & $9,119,149$ & 938,000 & $10.3 \%$ & $1,606.0 \%$ \\
Cuba & $11,326,354$ & 190,000 & $1.7 \%$ & $216.7 \%$ \\
United States & $331,473,276$ & $\mathbf{2 2 9 , 1 3 8 , 7 0 6}$ & $69.1 \%$ & $112.0 \%$ \\
\hline
\end{tabular}

Source: Internet World Stats www.internetworldstats.com

Figure 5. Internet usage in selected Caribbean countries.

Two quantitative surveys were conducted to gauge the extent to which a) local businesses and b) local consumers are engaging in e-marketing activities.

a) Local Business Website Survey:

Sixty local companies were randomly selected and their websites viewed and then assessed on ten criteria loosely modeled after the six phases of Internet presence described by Schneider (2002: p. Xxxv). Points were awarded based on a "yes/no" scale, with yes getting one point and no zero points, resulting in an overall rating as follows:

8 - 10 points = Grade A—advanced Internet or "engaged in e-commerce";

$4-7$ points = Grade B-intermediate Internet presence or "structured website";

1 to 3 points = Grade C—basic Internet presence or "hello, I'm online, too";

0 points $=$ Grade $\mathrm{D}$-no website or observable e-marketing activities.

\section{b) Local Consumer Internet Usage Survey:}

One hundred individuals were randomly selected from amongst those standing in the checkout lines at Tru Valu Supermarket, Trincity. An equal number of male and females 18 years and over were targeted. The questionnaire assessed their current Internet usage habits and utilized a "yes/no" scale.

\section{Data Analysis and Results}

Of the companies surveyed as part of the local business website survey, $18 \%$ had little or no Internet presence (grade D), while $20 \%$ had an advanced Internet presence (grade A). While Consumer Goods represented 28\% of 
the industries surveyed, only 1 such company (6\%) received a grade A, most receiving a grade C. Retail, which represented $18 \%$ of the sample, had no grade A companies but 6 at grade D. Telecommunications received the only full marks with two out of two companies getting a grade A. Three out of three Utility companies received a grade B. Finance was the industry with the highest overall Internet presence rating (100\% grade A \& B combined). The local business website survey findings are summarized in Figure 6.

The results illustrate that there is fair amount of Internet activity taking place amongst local businesses; however, most of it is at a basic to intermediate level. In the United States, industries such as Consumer Goods and Retail are dominant players on the Internet. Locally, however, these industries under perform in terms of Internet presence. Few of these seem to have an Internet strategy in place. An overall $17 \%$ of companies received a grade $\mathrm{C}$, a fact that suggests that many companies are developing websites but are infrequently or never updating them. Fuelling this behavior, perhaps, might be the belief by local businesses that Internet usage amongst local consumers is minimal. Consumers, however, are clearly engaging in e-marketing activity. Figure 7 shows the local consumer survey sample composition and general statistics while Figure 8 summarizes the actual Internet usage results.

Notably, all of the individuals approached for the survey currently accessed and used the Internet. Seventy-three percent have dial up access and $82 \% \log$ on daily. The top three uses of the Internet were email (100\%), searching (100\%) and downloading/listening to music (84\%). Discussion forums were used the least (10\%). While only $22 \%$ currently engage in online shopping, $51 \%$ said that they would definitely consider it in the future. Similarly, 23\% said they would consider participating in a discussion forum (providing the topic was relevant).

The results suggest an increasing degree of consumer receptiveness towards e-marketing. Respondents indicated that they regularly visit sites such as Amazon, Google, CNN, BBC, etc. Clearly there is already a demand for online information yet there does not seem to be a corresponding supply of available, updated online information from local businesses.

\begin{tabular}{|c|c|c|c|c|c|c|c|c|c|c|}
\hline \multirow[b]{2}{*}{ Industry (Ind.) } & \multirow[b]{2}{*}{$\begin{array}{l}\text { \# of } \\
\text { Co.s }\end{array}$} & \multirow[b]{2}{*}{$\begin{array}{l}\% \text { of } \\
\text { Total }\end{array}$} & \multicolumn{2}{|c|}{ Grade A } & \multicolumn{2}{|c|}{ Grade B } & \multicolumn{2}{|c|}{ Grade C } & \multicolumn{2}{|c|}{ Grade D } \\
\hline & & & $\#$ & $\begin{array}{l}\% \text { of } \\
\text { Ind. }\end{array}$ & $\#$ & $\begin{array}{c}\% \text { of } \\
\text { Ind. }\end{array}$ & \# & $\begin{array}{l}\% \text { of } \\
\text { Ind. }\end{array}$ & $\#$ & $\begin{array}{l}\% \text { of } \\
\text { Ind. }\end{array}$ \\
\hline Consumer Goods & 17 & $28 \%$ & 1 & $6 \%$ & 5 & $29 \%$ & 6 & $35 \%$ & 5 & $29 \%$ \\
\hline Finance & 10 & $17 \%$ & 3 & $30 \%$ & 7 & $70 \%$ & 0 & $0 \%$ & 0 & $0 \%$ \\
\hline Hospitality & 3 & $5 \%$ & 0 & $0 \%$ & 3 & $100 \%$ & 0 & $0 \%$ & 0 & $0 \%$ \\
\hline Media \& Advertising & 7 & $12 \%$ & 3 & $43 \%$ & 3 & $43 \%$ & 1 & $14 \%$ & 0 & $0 \%$ \\
\hline Other & 7 & $12 \%$ & 3 & $43 \%$ & 2 & $29 \%$ & 2 & $29 \%$ & 0 & $0 \%$ \\
\hline Retail & 11 & $18 \%$ & 0 & $0 \%$ & 4 & $36 \%$ & 1 & $9 \%$ & 6 & $55 \%$ \\
\hline Telecommunications & 2 & $3 \%$ & 2 & $100 \%$ & 0 & $0 \%$ & 0 & $0 \%$ & 0 & $0 \%$ \\
\hline Utilities & 3 & $5 \%$ & 0 & $0 \%$ & 3 & $100 \%$ & 0 & $0 \%$ & 0 & $0 \%$ \\
\hline Total & 60 & $100 \%$ & 12 & $20 \%$ & 27 & $45 \%$ & 10 & $17 \%$ & 11 & $18 \%$ \\
\hline Grade as $\%$ of total & & & $20 \%$ & & $45 \%$ & & $17 \%$ & & $18 \%$ & \\
\hline
\end{tabular}

Figure 6. Local website survey results.

\begin{tabular}{|c|c|c|c|c|c|}
\hline \multicolumn{2}{|l|}{ Gender: } & \multicolumn{2}{|l|}{ Access Location: } & & \\
\hline Male & $50 \%$ & Home only & $30 \%$ & & \\
\hline \multirow[t]{2}{*}{ Female } & \multirow[t]{2}{*}{$50 \%$} & Work only & $15 \%$ & & \\
\hline & & Both & $55 \%$ & & \\
\hline \multicolumn{2}{|l|}{ Age Group: } & \multicolumn{2}{|l|}{ Connection at home: } & \multicolumn{2}{|c|}{ Frequency of use: } \\
\hline $18-29 y r s$ & $32 \%$ & Dial Up & $73 \%$ & Daily & $82 \%$ \\
\hline $30-39 y r s$ & $30 \%$ & High Speed/DSL & $19 \%$ & Weekly & $10 \%$ \\
\hline $40-59 y r s$ & $38 \%$ & Wireless Broadband & $8 \%$ & Monthly & $0 \%$ \\
\hline $60 y r s \&$ over & $0 \%$ & Other/ Don't know & $0 \%$ & Rarely & $8 \%$ \\
\hline
\end{tabular}

Figure 7. Local consumer survey sample composition and general statistics. 


\begin{tabular}{|c|c|c|c|}
\hline \multicolumn{2}{|l|}{ Current Uses of Internet } & \multirow{2}{*}{\multicolumn{2}{|c|}{$\begin{array}{l}\text { Types of e-marketing activities } \\
\text { *receptive towards: }\end{array}$}} \\
\hline Email & $100 \%$ & & \\
\hline Instant messaging & $69 \%$ & Email marketing & $63 \%$ \\
\hline Searching & $100 \%$ & Search Ads & $54 \%$ \\
\hline Online shopping & $22 \%$ & Website ads & $32 \%$ \\
\hline News \& updates & $71 \%$ & Online surveys & $41 \%$ \\
\hline Music (listen/download) & $84 \%$ & Discussion forums & $23 \%$ \\
\hline Movies (view/download) & $43 \%$ & Online shopping & $51 \%$ \\
\hline Online games & $20 \%$ & \multirow{6}{*}{\multicolumn{2}{|c|}{$\begin{array}{l}\text { *Receptive means that they are willing } \\
\text { and interest in receiving marketing } \\
\text { messages via these mediums. }\end{array}$}} \\
\hline Discussion Forums & $10 \%$ & & \\
\hline Chat rooms & $17 \%$ & & \\
\hline Online surveys & $29 \%$ & & \\
\hline Visit local websites: yes & $80 \%$ & & \\
\hline Visit local websites: no & $20 \%$ & & \\
\hline
\end{tabular}

Figure 8. Local consumer internet use survey results.

\section{Summary and Conclusions}

The Internet provides a vast array of marketing communication possibilities that allow for identification, interaction, differentiation and customization with virtually each consumer. Since its launch over 30 years ago, its development has been phenomenal not only in its impact but also in its rate of penetration. No other modern day technological invention has experienced such rapid growth. The proliferation of broadband Internet is largely responsible for the Internet quickly becoming the marketing medium of choice for both businesses and consumers, as it facilitates consumers' desire for personalized attention while allowing for marketing accountability unlike any other medium has thus far.

Trinidad and Tobago's rate of Internet adoption is behind much of the rest of the world. Internet and communications technologies have been identified as national strategic building blocks and plans have been established to rapidly bring the Internet within the reach of most households and businesses. Thus far, the local business community appears to have adopted a lethargic and conservative approach towards the Internet as strategic business tool. Local consumers, however, are leading the way and are not too far behind their counterparts in other parts of the world. Once the main obstacle of lack of access to broadband Internet disappears, there is likely to be a rapid increase in demand by local consumers for e-marketing and other online services from local businesses. Those businesses that act quickly and decisively will be the ones to whom local consumers turn to for products and services.

The evolution does not stop here, however, and some predict that we have only just seen the tip of the iceberg. Consumer-centric marketing will rise to new heights as new technologies enable even greater levels of multidevice Internet interactivity, for example, mobile phones and televisions, as opposed to mainly a computerbased Internet. The resulting network could be thousands times larger than the current one, thus creating even more opportunities and challenges for marketers everywhere.

The results of this study's primary research, if representative, do indeed suggest progress albeit little, in this country's level of Internet use by local businesses. However, given the rate of Internet development and evolution, Trinidad and Tobago must catch up with the rest of the world before the gap widens to a point where it becomes impossible to do so.

One recommendation is that qualitative studies be conducted amongst relevant members of the local business community to determine what their perceptions about the Internet and their assumptions about local consumer usage are. Combined with the quantitative results, the government may be better poised to address the deficiencies in its ICT implementation plan.

\section{References}

Amor, D. (2002). The e-Business (R)evolution: Living and Working in an Interconnected World. New Jersey: Prentice Hall PTR \& Hewlett-Packard Company, xxxiii, 176.

Applegate, L., Austin, R., \& McFarlan, F. (2002). Creating Business Advantage in the Information Age. New York, NY: McGraw-Hill/Irwin. 
Coen, R. (2006). U.S. Advertising Volumes 2000-2005. Universal McCann.

Drucker, P. (2001). The Essential Drucker. New York, NY: HarperCollins Publishers Inc.

Edison Media Research (2002). The Need for Speed.

http://www.edisonresearch.com/home/archives/NAB2001_LasVegas_Final.pdf

Internet World Stats (2006). Internet Usage in the Caribbean. http://www.internetworldstats.com/stats2.htm

Ministry of Finance (2006). National Budget 2006-2007.

Ministry of Planning and Development (2010). National ICT Plan Trinidad and Tobago 2012-2016.

Ministry of Public Administration \& Information (2003). Fast forward: Trinidad \& Tobago’s National Information \& Communication Strategy Summary Brochure. 3.

National e-Commerce Secretariat (2003). 2003 National Surveys on e-Commerce Usage \& Awareness among Businesses and Households.

PricewaterhouseCoopers (2003). The Broadband Future. 13. http://www.pwc.com/images/telecom/BBFutureUS.pdf

Schneider, G. (2003). Electronic Commerce. Boston, MA: Thomson Course Technology, xxxv, 178.

Who’s Who TNT (2003). Who’s Who in Trinidad \& Tobago Business. http://www.whoswhotnt.com 
Scientific Research Publishing (SCIRP) is one of the largest Open Access journal publishers. It is currently publishing more than 200 open access, online, peer-reviewed journals covering a wide range of academic disciplines. SCIRP serves the worldwide academic communities and contributes to the progress and application of science with its publication.

Other selected journals from SCIRP are listed as below. Submit your manuscript to us via either submit@scirp.org or Online Submission Portal.
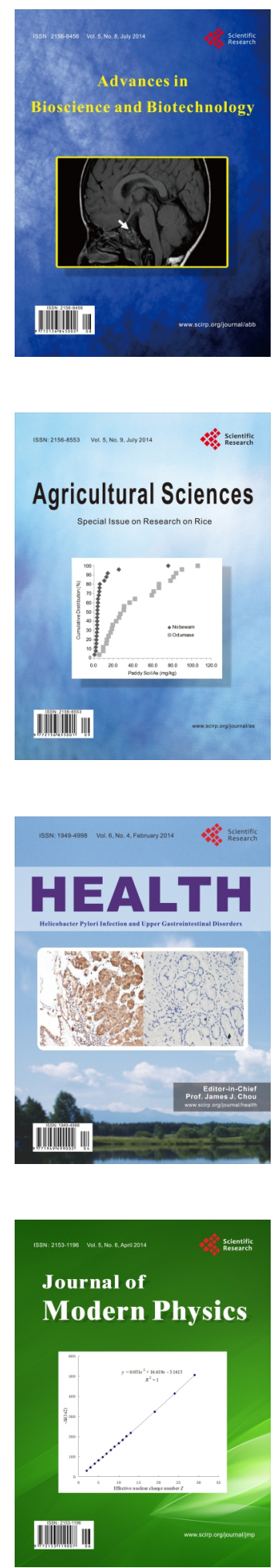
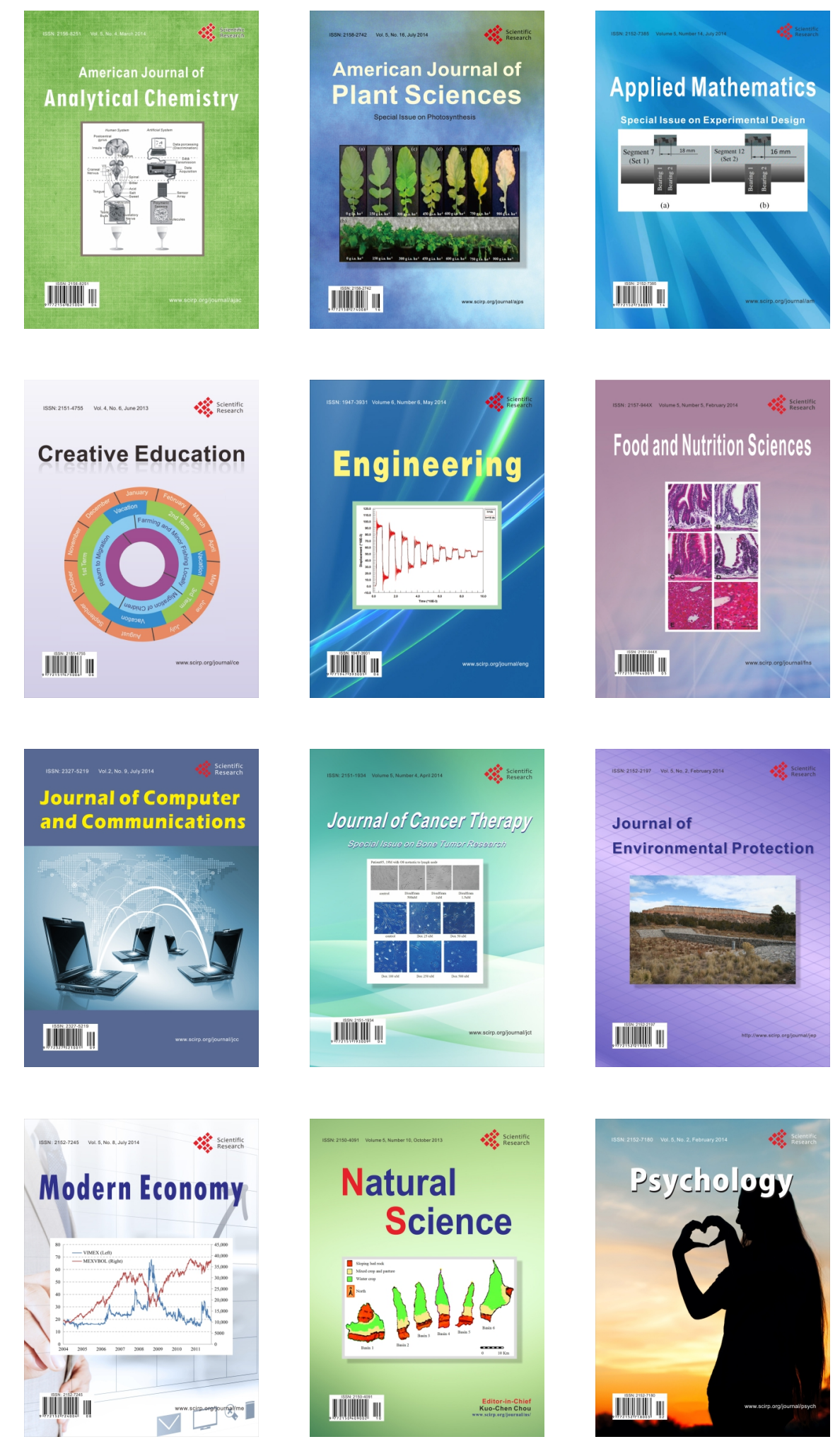